\title{
エキシマレーザによる多層基板の 微細穴あけ加エシステム
}

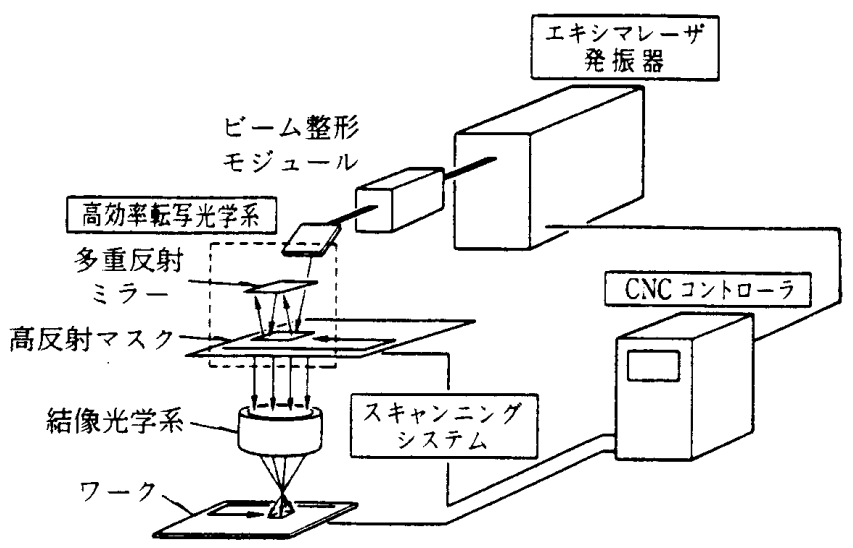

図 1 装置の構成

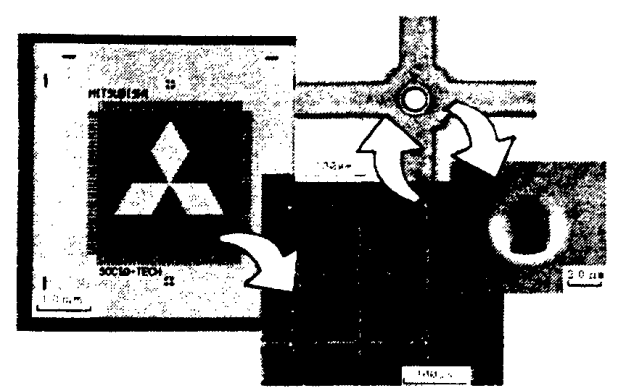

図 2 銅/ポリイミド基板のバイア ホール加工
1. はじめに 最近のパソコ ンやワークステーションの高性能 化, 移動体通信やマルチメディア 機器の登場に伴い，プリント基板 の多層化, 高密度化が進んでい る。従来, 層間の配線を行う微細 穴は感光性樹脂を用いた露光，現 像プロセスにより加工するのが一 般的であった。しかしながら，次 のような理由から，エキシマレー ザがこれに代わる加エツールとし て注目を浴びている。

（1） 従来法では加工が困難な微 細（数十 $\mu \mathrm{m})$, 高アスペクト比 (1 4 程度) 加工が可能.

（2）絶縁材料に感光性を要求し ないので，安価な材料が使用でき る.

(3) ドライプロセスなので溶乳 の処理が不要.

ここで，レーザとしてエキシマ レーザが選ばれているのは，エキ シマレーザは紫外の波長領域の光 を高輝度で発振できるため $\mathrm{CO}_{2}$ レーザなどの熱加工とは異なった 光化学加工が可能なためであ る ${ }^{(1)}$.このような背景の中, 各社 よりエキシマレーザ加工装置が市 販されているが，多層基板の量産
用としては，加エスループット， ランニングコスト，メンテナンス 性など多くの問題が残っている。 当社ではこれらの課題を解決した 生産性の高いエキシマレーザ加工 システムを開発したので以下に紹 介する(2).

2. 權成図 1 に装置の基本 構成を示す。この装置は以下のコ ンセプトで製品化されたものであ る.

（1）エキシマレーザ発振器は長 寿命化を最優先し, 出力は $24 \mathrm{~W}$ に抑えフフォトンコストは当社従 来比 $1 / 10$ 以下とする。

(2) マスクからの反射光を有効 利用する多重反射光学系の開発に より，マスクを照射するレーザパ ワーを $300 \mathrm{~W}$ 相当に高める.

(3) マスクと基板を同期スキャ ンすることにより大面積加工を可 能とする。

3. 基本性能および加工例 この装置は, $100 \mathrm{~mm}$ 角，厚さ 25 $\mu \mathrm{m}$ のポリイミドシート全面に数 万個の微細穴（最小穴径 $10 \mu \mathrm{m}$ ) を約 1 分で加工できる。このとき の総合加工位置精度は $\pm 15 \mu \mathrm{m}$ 以 下である. 図 2 は MCM (マルチ
チップモジュール）モデル基板の 加工例で，銅パターン（配線幅 $50 \mu \mathrm{m}$ ，ピッチ $440 \mu \mathrm{m}$ ，ランド径 $90 \mu \mathrm{m})$ 上のポリイミドに径 30 $\mu \mathrm{m}$ の全面穴あけ加工を行ったも のである(3). 加工対象としては, ポリイミドのほかにグリーンシー トも可能である.

4. おわりにここでは多層 基板の加工についてのみ触れた が，エキシマレーザはインクジェ ットプリンタのノズル加エやワイ ヤストリッピング加工にも実用化 されており，今後さらに応用分野 が広がると予想される。

\section{文献}

（1）矢部・ほか，エキシマレーザによ る化学プロセス, 化学技術研究所 報告, 84-7（1989），401。

（2）江浦・ほか，量産用エキシマレー ザ加工システム，三菱電機技報， 68-9 (1994), 821

（3）伊滕・ほか, エキシマレーザによ る多層基板の微細穴あけ加エシス テム，電子材料， 33-10（1994） 89.

〔中谷 元 三菱電機 (株)] (原稿受付 1994 年 11 月 7 日) 